$1-1-1976$

\title{
Michelin Tire Corp. v. Wages: Enhanced State Power to Tax Imports
}

Walter Hellerstein

University of Georgia School of Law, wallyh@uga.edu

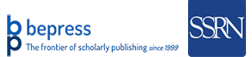

\section{Repository Citation}

Walter Hellerstein, Michelin Tire Corp. v. Wages: Enhanced State Power to Tax Imports (1976), Available at: https://digitalcommons.law.uga.edu/fac_artchop/486

This Article is brought to you for free and open access by the Faculty Scholarship at Digital Commons @ University of Georgia School of Law. It has been accepted for inclusion in Scholarly Works by an authorized administrator of Digital Commons @ University of Georgia School of Law. Please share how you have benefited from this access For more information, please contact tstriepe@uga.edu. 


\section{MICHELIN TIRE CORP. v. WAGES:}

\section{ENHANCED STATE POWER}

\section{TO TAX IMPORTS}

In Michelin Tire Corp. v. Wages, ${ }^{1}$ the Supreme Court abandoned a century of precedent in holding that the Import-Export Clause ${ }^{2}$ does not bar a state from imposing a nondiscriminatory ad valorem property tax on imported goods. The provision forbidding the states from laying "any Imposts or Duties on Imports or Exports"3 was never intended to prohibit such a levy, the Court now tells us, and the case first suggesting that it did, Low v. Austin, ${ }^{4}$ was "wrongly decided." ${ }^{5}$ Over a mild protest of Mr. Justice White, ${ }^{6}$ the Court thus obviated any examination of the principal issue the parties had briefed: whether Michelin's tires, while sitting in a warehouse in Gwinnett County, Georgia, had retained their "distinctive charac-

Walter Hellerstein is Assistant Professor of Law, The University of Chicago. The author wishes to thank Professors Walter J. Blum, Gerhard Casper, Kenneth W. Dam, Jerome R. Hellerstein, Phil C. Neal, and Geoffrey R. Stone for their helpful comments on an earlier draft of this article.

1423 U.S. 276 (1976).

2 U.S. Const., Art. I, $\$ 10, \mathrm{cl} .2$.

${ }^{3} \mathrm{Id}$. The complete text of the Clause reads: "No State shall, without the Consent of the Congress, lay any Imposts or Duties on Imports or Exports, except what may be absolutely necessary for executing its inspection Laws: and the net Produce of all Duties and Imposts, laid by any State. on Imports or Exports, shall be for the Use of the Treasury of the United States; and all such Laws shall be subject to the Revision and Controul of the Congress."

*13 Wall. 29 (1872).

5423 U.S. at 301.

${ }^{6} I d$. at 302. 
ter" as imports and, consequently, their immunity from state taxation.

Although the Court's confession of error apparently spared us a discourse on the "original package" doctrine, ${ }^{7}$ it could hardly fail to raise a number of questions. Some are historical. Are we assured that the Court, now fortified by "scholarly analysis," is correct in its confident assertion that " $[\mathrm{n}]$ othing in the history of the ImportExport Clause even remotely suggests that a nondiscriminatory ad valorem property tax which is also imposed on imported goods that are no longer in import transit was the type of exaction that was regarded as objectionable by the Framers"? ${ }^{9}$ Others are jurisprudential. Was there any "reason" or "necessity" to overrule Low v. Austin since, as Mr. Justice White remarked, "None of the parties has challenged that case here, and the issue of its overruling has not been briefed or argued"? ${ }^{10}$ And still others are of immediate practical importance. In delimiting the power of states to tax imports, should we continue to ask: "When does an import cease to be an import?"11 or should we address other issues instead? Extended consideration of each of these questions may be warranted, but it is toward the last area of inquiry that this article is primarily directed. ${ }^{12}$

\section{The Michelin Decision}

\section{A. THE FACTS}

While most of the facts turned out to be largely beside the point, their brief recitation is necessary to an understanding of the issue the parties thought they were litigating.

${ }^{7}$ Cf., e.g., Hooven \& Allison Co. v. Evatt, 324 U.S. 652 (1945).
8423 U.S. at 282.
${ }^{9} I d$. at 286.

${ }^{10} I d$. at 302. Although the "parties" may not have challenged Low, amici curiae surely did. See Amici Curiae Brief for the County of Los Angeles, pp. 19-42. And petitioner responded to the "arguments which ask this Court to overrule Brown $\approx$. Maryland, Low v. Austin and other decisions" by suggesting that "Congress, rather than this Court, is the appropriate tribunal to consider and pass on this group of arguments." Reply Brief for Petitioner, p. 2.

${ }^{11}$ The question is Professor T. R. Powell's. Powell, State Taxation of ImportsWhen Does an Import Cease to Be an Import? 58 Harv. L. Rev. 858 (1945).

${ }^{12}$ The historical issues have been explored at length elsewhere. See, e.g., 1 Crosskey, Politics and the Constitution in the History of the United States 295-323 (1953); Early \& Weitzman, A Century of Dissent: The Immunity of Goods Imported for Resale from Nondiscriminatory State Personal Property Taxes, 7 S.W.U.L. REv. 247 (I975). 
The Michelin Tire Corporation, a New York subsidiary of its French parent, ${ }^{13}$ operated as an importer and wholesale distributor in the United States of automobile and truck tires and tubes manufactured in France and Canada. Michelin operated distribution warehouses for its products in various parts of the country. One such warehouse was located in Gwinnett County, Georgia. Imported tires and tubes were shipped to this warehouse in two ways. Approximately 75 percent, including all those imported from France, were transported in sea vans, which are over-the-road trailers with removable wheels. The vans were packed and sealed at the foreign factory, hauled to a port where the wheels were removed, and loaded on ships bound for the United States. At the port of entry, the vans were unloaded, their wheels were replaced, and they were hauled to the Gwinnett County warehouse, usually arriving within a week. The remaining 25 percent of the tires and tubes were transported from Canada in over-the-road trailers. They were packed and sealed at the Canadian factory and delivered directly to the Gwinnett County warehouse. Michelin owned none of the sea vans or trailers in question and there was no intermediate distribution point for any of the shipments.

The imported tires were packed into the sea vans and trailers in bulk without otherwise being packaged or bundled. Upon arrival at the warehouse, each van or trailer load of tires was unloaded, sorted by size and style, and stored in the warehouse awaiting distribution without further processing. ${ }^{14}$ The imported tubes were individually packaged in small boxes and were transported in the sea vans and trailers in larger corrugated cartons. Upon arrival at the warehouse, the shipments of tubes were unloaded, sorted, and segregated by size. Most of the tubes were stored in the larger cartons, but some had been removed from the cartons and held available for sale in small quantities. Except for a few domestic tubes purchased by Michelin when it was experiencing difficulty obtaining its imported tubes, ${ }^{15}$

132 Directory of INTER-CORporate OWNership (Who OWN Whom in AMERica) 776 (Angel Comp. 1974).

${ }^{14}$ Both the United States Supreme Court, 423 U.S. at 280, and the Georgia Supreme Court, $233 \mathrm{Ga}$. at $713-14$, made statements to the effect that at this point the individual shipments ceased to be separate identifiable units. The tires were in fact identifiable by serial number. 423 U.S. at 280 .

15 Record, pp. App. 29-30. "Domestic tubes are similarly packaged and similarly handled at the warehouse." $233 \mathrm{Ga}$. at 714. On both tax dates in question, some domestic tubes were stored in the warehouse. 
all the tires and tubes in the warehouse were imported from abroad and transported and stored in the manner indicated.

The Gwinnett County warehouse served as the distribution center for Michelin tires and tubes to franchised dealers in six southeastern states. All the tires and tubes in the warehouse were sold and distributed to such dealers, who numbered between 250 and 300 . Orders from the dealers were filled without regard to the shipments in which the tires and tubes arrived in the United States or their place of manufacture. Orders varied in size, but they averaged $4,000-5,000$ pounds per sale. ${ }^{16}$ Delivery to the franchised dealers was by common carrier or customer pickup. No tires were sold directly to retail customers. Michelin paid a 4 percent federal duty on all of its imports.

In 1973, the tax commissioner and tax assessors of Gwinnett County, Georgia, assessed ad valorem property taxes against Michelin's inventory held in its warehouse on 1 January 1972 and 1 January $1973 .{ }^{17}$ The assessments averaged about $\$ 10,000 .{ }^{18}$ Alleging that all the tires and tubes located in its warehouse were immune from Gwinnett County property taxes under the Import-Export Clause, except for the imported passenger tubes that had been removed from their original shipping cartons, ${ }^{19}$ Michelin filed a complaint in the Superior Court of Gwinnett County seeking declaratory and injunctive relief against enforcement of the tax.

\section{B. THE STATE COURT PROCEEDINGS}

It is apparent from the record that counsel for both the tax authorities and the taxpayer viewed Michelin's lawsuit as an oppor-

\footnotetext{
${ }^{16}$ An average shipment of tires on a sea van would weigh 23,000 to 25,000 pounds. Record, pp. App. 54.

${ }^{17}$ All real and personal property in Georgia, unless specifically exempted, is subject to taxation. GA. Cone ANN. $\$ 92-101$ (1974). The county is authorized to levy taxes for current expenses, accumulated debts, and for other county purposes. $I d$. at $\$ \S 92-3702-17$. The order assessing the county tax for the year must specify the percent levied for each specific purpose. $I d$. at $\$ 92-3801$. The county tax authority is obligated to have a statement prepared of the amount of tax required for county purposes for each year. $I d$. $\$ 92-3709$. The assessment also applies to property taxed by the state. Id. at $\$ 92-3801$. All tangible property is assessed at 40 percent of fair market value. Id. at $\$ 92-5703$. The tax rate is the aggregate of all lawful levies. CCH State TAX Guide (All States Unit) \ 20-354 (1974).

18 Plaintiff's Complaint, $\$ 5$, Record, p. App. 3.

${ }^{19}$ After its complaint was filed, Michelin discovered that some of the tubes it had claimed to be exempt were in fact of domestic origin and therefore not exempt. See Record, pp. App. 19-21. Michelin paid taxes on these tubes.
} 
tunity to obtain guidance from the courts as to the scope of the Import-Export Clause's prohibition against state taxes. Counsel for the county stated to the trial court that: ${ }^{20}$

a complete record would be built in this case . . because we need direction in this particular matter. ... [W] e have now, I believe-what four or five importers operating in the country $[s i c]$... so its getting to be a mass-substantial amount of tax involved and we need some direction in how to handle this matter and that's really why we brought the matter to a head this way, to find out really where we stand.

Counsel for Michelin expressed similar sentiments. ${ }^{21}$

After a brief bench trial that established the record of virtually undisputed facts, the court granted Michelin the requested relief. The trial court's opinion recited the classic formulation from the seminal case of Brown v. Maryland: ${ }^{22}$

It is sufficient for the present to say, generally, that when the importer has so acted upon the thing imported, that it has become incorporated and mixed up with the mass of property in the country, it has, perhaps, lost its distinctive character as an import, and has become subject to the taxing power of the State; but while remaining the property of the importer, in his warehouse, in the original form or package in which it was imported, a tax upon it is too plainly a duty on imports to escape the prohibition in the constitution.

The court noted that this principle had been extended to immunize imported goods from ad valorem property taxes. It construed the facts in light of this principle: ${ }^{23}$

The automobile and truck tires here involved while perhaps not in an original package are without doubt in the original form in which they were imported into this Country. Most tubes are in the original containers. Those tubes taken from the original containers have been included in inventory and tax paid on them.

And finally, while opining that "tires and tubes ... placed in plaintiff's general inventory for the purpose of sale to its customers ...

\footnotetext{
${ }^{20}$ Record, p. App. 25.

${ }^{21} \mathrm{ld}$. at 26.
}

2212 Wheat. 419, 441-42 (1827).

${ }^{23}$ Petition for Certiorari, p. A-4. 
should be taxed to the same extent as any other inventory of any other business in Gwinnett County, and the Court would so hold if supported by the law," it felt constrained "to bow to the authorities and hold that the automobile and truck tires in plaintiff's inventory are imports and until they have been sold are not subject to any ad valorem tax that may be levied against them by Gwinnett County."24

As anticipated, the county officials appealed to the Georgia Supreme Court. That court, evidently less impressed than the county tribunal by "the authorities," engaged in an analytic exercise that has typified opinions in this area ever since Chief Justice Marshall suggested that immunity of imports from state taxation may have something to do with "the original form or package" in which they are imported. Notwithstanding the admonition that " $[i] \mathrm{t}$ is a matter of hornbook knowledge that the original package statement of Justice Marshall' was an illustration, rather than a formula, and that its application is evidentiary, and not substantive," ${ }^{25}$ the Georgia Supreme Court undertook a lengthy exegesis of the "original package" doctrine.

Through its opinion, a kaleidoscope of goods and packages was paraded before our eyes against an essentially ${ }^{26}$ unchanging doctrinal backdrop. French champagne stored by the importer in a San Francisco warehouse, "whilst remaining in the original cases, unbroken and unsold," enjoyed immunity from state taxation. ${ }^{27}$ European dry goods packed in separate parcels or bundles but exposed or offered for sale in opened shipping boxes did not. ${ }^{28}$ An importer of hundred-pound bags of Chilean nitrate stored in an Alabama warehouse and kept in the original packages until sold enjoyed immunity from state taxation. ${ }^{29}$ A wholesaler of fish caught in the Gulf of Mexico who is assessed by their weight after washing and reicing did

\footnotetext{
${ }^{24}$ Ibid.

${ }^{25}$ City of Galveston v. Mexican Petroleum Corp., 15 F.2d 208 (S.D. Tex. 1926).

${ }^{26}$ Bur see note 32 infra.

${ }^{27}$ Low v. Austin, 13 Wall. 29, 32 (1872) (ad valorem property tax), considered $233 \mathrm{Ga}$. at 716.

${ }^{28}$ May v. New Orleans, 178 U.S. 496 (1900) (ad valorem property tax), considered $233 \mathrm{Ga}$ at 716.

${ }^{29}$ Anglo-Chilean Nitrate Sales Corp. v. Alabama, 288 U.S. 218 (1933) (franchise tax), considered $233 \mathrm{Ga}$. at 717.
} 
not. ${ }^{3 n}$ Bales of Philippine hemp stored in an Ohio warehouse awaiting use in the manufacture of cordage and similar products enjoyed immunity from state taxation. ${ }^{31}$ Piles of foreign ore and plywood awaiting use in manufacturing processes did not. ${ }^{32}$

At the same time, the opinion raised a host of theoretical questions bearing on the application of the doctrine. Are sea vans and trailers considered to be the "original packages"? 33 Do unpackaged imports enjoy an immunity different in scope from packaged imports, ${ }^{34}$ and, in any event, how does one apply the doctrine to an unpackaged import that never changes its "original form"? there a distinction between the application of the doctrine to goods imported for use and goods imported for sale? ? $^{36}$

${ }^{50}$ Gulf Fisheries Co. v. MacInerney, 276 U.S. 124 (1928) (license tax), considered $233 \mathrm{Ga}$. at $716-17$.

${ }^{31}$ Hooven \& Allison Co. v. Evatt, 324 U.S. 652 (1945) (ad valorem property tax), considered 233 Ga. at 717.

32 Youngstown Sheet and Tube Co. v. Bowers and United States Plywood Corp. v. City of Algoma, 358 U.S. 534 (1959) (ad valorem property taxes), considered 233 Ga. at 717-18. The Court in Youngstown noted, inter alia, "Whatever nuay be the significance of retaining in the 'original package' goods that have been so imported for sale ... goods that have been so imported for use in manufacturing are not exempt from taxation, though not removed from the 'original package,' if, as found here, they have been 'put to the use for which they [were] imported.'" 358 U.S. at 548. Whether Youngstown undermined the "original package" doctrine or merely announced a rnle for cases involving a manufacturer's "current operating needs," id. at 549, has been the subject of some discussion. Sce Justice Frankfurter's disscnting opinion, id. at 551-75. See also Dakin, The Protective Cloak of the ExportImport Clause: Imminity for the Goods or lmminity for the Process? 19 LA. L. Rev. 747 (1959); Early \& Wcitzman, note 12 supra.

${ }^{m}$ Compare Volkswagen Pacific, Inc. v. City of Los Angeles, 7 Cal.3d 48 (1972) (sea van constitutes "original package"), considered 233 Ga. at 719, witb Garment Corp. of America v. State Tax Comm'n, 32 Mich. App. 715 (1971) (sea van does not constiture "original package"), considered $233 \mathrm{Ga}$ at 721.

24233 Ga. at 723.

${ }^{35}$ Sce, e.g., E. J. Stanton \& Sons v. Los Angeles County, 78 Cal. App.2d 181 (1947), considered $233 \mathrm{Ga}$. at 719-20, where the California court waxed lyrical in approaching the problem: "A cargo of planks, timbers or logs imported from foreign lands is surrounded by an invisible gossamer woven of law, custom and convention which protects the merchandise from the local tax assessor only so long as it retains the unbroken wrapper in wltich it entered the port. But when such cargo sheds its invisible cover, even thougl in the warehouse of the iniporter, and is so sorted and classified as to facilitate its sale . . . termination of immunity [is compelled]." Id. at 187-88. See generally Trickett, The Original Package Ineptitude, 6 Colum. L. Rev. 161 (1906).

${ }^{56}$ See note 32 supra. 
The Georgia Supreme Court, while rejecting the argument that an ad valorem property tax does not fall within the prohibition of the Import-Export Clause, ${ }^{37}$ had little difficulty in concluding that most of Michelin's inventory was constitutionally taxable. In its view, the unpackaged tires, once sorted, segregated by size and style, and commingled with other shipments had lost their status as imports and were subject to taxation. Not so, however, the packaged tubes in corrugated cartons, which retained their immunity under the "original package" doctrine: 38

This doctrine has been almost universally applied, in a mechanical way, for about 150 years. The great weight of authority makes a vast distinction between goods shipped in packaging, such as crates or cartons, and goods shipped in bulk. Packaged imports retain their status as imports, and are not subject to taxation. Bulk imports that have been mingled with other bulk imports, sorted, and arranged for sale do not retain their status as imports, and they are subject to taxation.

Unhappy with this disposition of the matter, Michelin petitioned the United States Supreme Court for certiorari. The Gwinnett County tax officials, apparently not wishing to challenge the application of the "original package" doctrine to Michelin's tubes that remained in the shipping cartons, did not cross-petition from the Georgia court's affirmance on this point. Thus, when the Supreme Court granted Michelin's petition, the only question presented was whether the Georgia Supreme Court was correct in holding that Michelin's tires were subject to Gwinnett County's ad valorem property tax, a question both parties framed in terms of the physical packaging, form, and arrangement of the tires. ${ }^{39}$

\section{THE SUPREME COURT'S OPINION}

The Supreme Court affirmed not on the ground that the state court had accurately drawn the line between tax-immune imports and goods that had become "incorporated and mixed up with the mass of property in the country," 40 but on the ground that "Georgia's assessment of a nondiscriminatory ad valorem property tax

\footnotetext{
${ }^{37} 233 \mathrm{Ga}$. at 722.

38 Id. at 723.

${ }^{39}$ Petition for certiorari, p. 2; Opposition to Petition for Certiorari, p. 2.

${ }^{40}$ Brown v. Maryland, 12 Wheat. at 441.
} 
against the imported tires is not within the constitutional prohibiagainst 'laying any Imposts or Duties on Imports . . ' and that insofar as Low v. Austin, 13 Wall. 29 ( 1872 ) is to the contrary, that decision is overruled."41 What induced the Supreme Court to discard Low is a matter for speculation, ${ }^{42}$ but its opinion in Michelin marks a fundamental reexamination of the purpose and scope of the ImportExport Clause's prohibition against state taxation of imports. In contrast to its past opinions in this area, which have often been characterized by a mechanistic application of Marshall's "original package" language in Brown v. Maryland to determine whether the goods under consideration had ceased to be "imports,"43 the Court's opinion explicitly refrained from addressing the question whether Michelin's tires had lost their status as "imports." 44 Instead the Court focused upon the nature of the exaction at issue to ascertain whether it constituted a forbidden "impost" or "duty." Although the determination whether an exaction is an "impost" or "duty" would not necessarily render academic the question whether the levy had been imposed upon an "import," 45 the Court's approach to the former issue appears substantially to reduce the need for inquiring into the latter. ${ }^{40}$

In returning to the original purposes of the constitutional prohibition against state taxation of imports, the Court identified three principal concerns of the Framers. First, "the Federal Government must speak with one voice when regulating commercial relations with foreign governments, and tariffs, which might affect foreign relations, could not be implemented by the States consistently with that exclusive power." 47 Second, "import revenues were to be the major source of revenue of the Federal Government and should not be diverted to the States." 48 Third, "harmony among the States might

11423 U.S. at 279.

${ }^{12}$ Conceivably, it was persuaded by the arguments of the California and Texas brief amici curiae on tbis score. The importance of the question to states and localities may have been underscored by the submission of amici curiae briefs by Kansas, Ohio, and Georgia, although these states did not argue that Low had been wrongly decided.

${ }^{43}$ See cases cited at notes 27-32 supra.

4423 U.S. at 279.

15 The conclusion that a tax is not an "impost" or "duty" would obviate any inquiry into whether it had been imposed upon an "import." The opposite conclusion would leave this issue open.

${ }^{43}$ See text infra at notes 76-99.

48 Ibid.

47423 U.S. at 285. 
be disturbed unless seaboard States, with their crucial ports of entry, were prohibited from levying taxes on citizens of other States by taxing goods merely flowing through their ports to the inland States not situated as favorably geographically." $"$ s9

Measured against these concerns, the Court could perceive nothing objectionable in a nondiscriminatory ad valorem property tax imposed on imports no longer in transit. It was "obvious" to the Court that such a tax could have "no impact whatsoever on the Federal Government's exclusive regulation of foreign commerce," because such a tax did not fall on imports "as such," could not be used "to create special protective tariffs or particular preferences for certain domestic goods," and could not be "applied selectively to encourage or discourage any importation in a manner inconsistent with federal regulation." making what amounts to little more than a tautological assertion that a nondiscriminatory tax does not have characteristics of a discriminatory tax, it is not altogether clear why it is so "obvious" that a nondiscriminatory state tax can have "no impact whatsoever" on the federal government's exclusive regulation of foreign commerce. If, for example, the Framers had intended that the federal government's plenary power over foreign commerce should extend to importers and their goods until the first sale in this country, the imposition of a variety of nondiscriminatory ad valorem property taxes by different states upon such goods prior to such sale might well be regarded as inconsistent with the constitutional plan, since they could subject importers and their goods to unequal economic and administrative burdens that could undermine federal control. Whether in fact the Import-Export Clause embodies such a design is, to be sure, a different question..$^{51}$ And it would be taking liberties with Marshall's language to so argue on the basis of his approval of counsel's contention in Brown v. Maryland that "the importer purchases, by payment of the duty to the United States, a right to dispose of his merchandise."

${ }^{49} \mathrm{Id}$. at $285-86$.

${ }^{50} I d$. at 286.

${ }^{51}$ In this connection, one might want to consider whether the exception to the Clause's prohibition for those imposts and duties that are "absolutely necessary for executing [a state's] inspection Laws" provides grounds for challenging the imposition of other burdens on imports under the inclusio unius exclusio alterins principle.

5212 Wheat. at 442. Counsel for Michelin did in fact so argue. Reply Brief for Petitioner, p. 3. Even if "the right to sell" is the "consideration for which the duty is paid," 12 Wheat. at 442, it hardly follows inexorably that the right includes a right to be free from a state's nondiscriminatory ad valorem property tax. 
Nevertheless, the Court accomplishes nothing by overstating its case, and implicitly attributing to nondiscriminatory taxes virtues they may not possess.

The Court likewise found no inconsistency between the imposition of nondiscriminatory ad valorem property taxes by the states and the Framers' second purpose in committing exclusive power to the federal government to lay imposts and duties on imports: the protection of the federal government's major source of anticipated revenues. The Court's reasoning was in part defimitional: "[I]f nondiscriminatory ad valorem taxation is not in that category [of imposts and duties on imports], it deprives the Federal Government of nothing to which it is entitled." 53 In supporting its position that such taxes do not fall within the defined category, the Court again returns to the point that it regards as most critical, the nondiscriminatory character of the levies: "It should be emphasized . . that they cannot be selectively imposed and increased so as substantially to impair or prohibit importation." 54 The impact that nondiscriminatory taxation might have on federal import revenues, "to the extent its economic burden may discourage purchase or importation of foreign goods," "5s was, the Court now firmly asserts, merely an "incidental effect" the prohibition of which was not "even remotely an objective of the Framers."

Nor, in the Court's view, would the imposition of nondiscriminatory ad valorem property taxes frustrate the third objective underlying the Import-Export Clause: preserving harmony and maintaining the free flow of imported goods among the states by preventing some states from exploiting their favorable geographic location by taxing goods destined for other states. Here the Court is a bit more tentative. It is no longer "obvious" that such levies could have "no impact whatsoever" on the stated purpose. Nor is it apparent that prohibition of such levies was not "even remotely an objective of the Framers." It is now by comparison to the exactions imposed by the states under the Articles of Confederation that such nondiscriminatory taxes "do not interfere with the free flow of imported goods." In fact, the Court acknowledges that "allowance of nondiscriminatory ad valorem property taxation may increase the cost of goods purchased by 'inland' consumers"v8 but finds such taxation justified
53423 U.S. at 286-87.
55 Id. at 287.
57 ld. at 288.
54 Id. at 287-88.
5 Ibid.
5s lbid. 
in part by the countervailing consideration that it represents the "quid pro quo for benefits actually conferred by the taxing State" for which ultimate consumers rather than local taxpayers should pay. ${ }^{59}$ Yet, in recognition of the possibility of a conflict between such taxes and this third purpose of the Import-Export Clause, the Court not only feels compelled to assure us that the purpose will still be secured under the Clause "merely by prohibiting the assessment of even nondiscriminatory property taxes on goods which are merely in transit through the State when the tax is assessed," ${ }^{60}$ but, as if harboring some doubts about the force of this prohibition, it allays further fears by reminding us that traditional Commerce Clause doctrine would likewise afford protection against interference with the free flow of goods. ${ }^{\text {1 }}$

Indeed, the Court's gingerly treatment of this issue may have stemmed from its experience under the Commerce Clause. The Court had there developed a doctrinal limitation on the constitutionality of nondiscriminatory state taxes, the "multiple burdens" theory: ${ }^{62}$

[T] he state may not impose certain taxes on interstate commerce, its incidents or instrumentalities, which are no more in amount or burden than it places on its local business, not because this of itself is discriminatory, cumulative or special or would violate due process, but because other states also may have the right constitutionally, apart from the commerce clause, to tax the same thing and either the actuality or the risk of their doing so makes the total burden cumulative, discriminatory or special.

The Court may well have sensed, though it was not willing to say so explicitly, that nondiscriminatory property taxes imposed on goods stored by an importer-wholesaler such as Michelin for distribution throughout the United States might in fact interfere with the free flow of imports among the states "by virtue of the cumulative impact of such taxes on the price of goods on their way to become part of a stock of goods for resale locally."

\footnotetext{
${ }^{59} I d$. at 289.

6o Id. at 290.

${ }^{61}$ Id. at 290, n.11.

${ }^{62}$ International Harvester Co. v. Department of Treasury, 322 U.S. 340, 358 (1944) (Rutledge, J., concurring). See Hellerstein, State Taxation of Interstate Business and the Supreme Court, 1974 Term: Standard Pressed Steel \& Colonial Pipeline, 62 VA. L. Rev. 149, 150-51, n.6 (1976).

${ }^{63}$ Dakin, note 32 supra, at 766. Cf. Crosskex, note 12 szupra, at 296, of the opinion that a nondiscriminatory property tax could not "entail any multiple burdening of
} 
Having thus demonstrated that the objectives of the ImportExport Clause would not be served, except to the limited extent noted, by prohibiting nondiscriminatory ad valorem property taxes on imported goods, the Court turned to the text. Conceding that the Clause did not by its terms except nondiscriminatory taxes from its prohibition, the Court pointed out that it was equally clear that not every tax-but only "imposts or duties"-lay within its scope. Noting that the constitutional grant of power to Congress "to lay and collect Taxes, Duties, Imposts, and Excises" ${ }^{44}$ supported a reading of the Import-Export Clause as not forbidding every tax which falls in some measure on imports, the Court drew upon Professor Crosskey's "persuasive demonstration" and "duties" were understood in 1787 to be exactions upon imports or importation as such. Bolstered by its perusal of Crosskey's interpretation of the "True Meaning of the Imports and Exports Clause," the Court concluded that there was sufficient ambiguity in the language of the Clause to preclude a construction that would not further its objectives, as prohibition of nondiscriminatory ad valorem property taxation would not.

It remained only for the Court to explain the error of its previous ways. Brown v. Maryland was precisely the type of case to which the Import-Export Clause was directed. It involved a fee levied by a coastal state on importers for a license they were required to obtain before selling within the state. Since such a fee was equivalent to a discriminatory tax on the goods themselves, which fell squarely within the Clause's prohibition, it could not stand. Although the Court in Brown devised the celebrated "original package" test as an

'Imports and Exports', except through the accidents of different tax-days upon transported goods, in the state of their origin and destination; and from any unfairness arising from this, the taxpayer ordinarily can escape by his own foresight and good management."

${ }^{24}$ U.S. Const. Art. $1, \S 8, \mathrm{cl} .1$.

65423 U.S. at $290-91$.

"OS Crossker, note 12 supra, at 295. Other aspects of Crosskey's views on the Import-Export Clause are inconsistent with existing constitutional doctrine. Crosskey believed that the Import-Export Clause applied to interstate "imports" as well as those shipped from abroad, $i d$. at 296-304, a view apparently shared by Chief Justice Marshall. See Brown v. Maryland, 12 Wheat. at 449 . But the Court rejected this interpretation in Woodruff v. Parham, 8 Wall. 123 (1868). Crosskey contended that "It the changed usage of "imports" and "exports," in modern times, has effectively concealed that the old tax barriers to trade between state and state were, in fact, specifically dealt with; it has therefore given to Justice Miller's strange opinion about the Imports and Exports Clause, in the Woodruff case, a wholly undeserved and increasing respectability." CrosskeY, note 12 supra, at 323. 
evidentiary tool for determining when imported goods had lost their status as imports and thus the protection of the Clause, this was but one of the situations in which it indicated that the prohibition would not apply. The other was when the particular state tax was not a proscribed "impost" or "duty," a point the Micbelin Court had taken some pains to make and one which it was now prepared to find "clearly implied" in Brown. ${ }^{67}$ In Low v. Austin, ${ }^{68}$ however, the Court had, with "no analysis," ignored "the language and objectives of the Import-Export Clause, and . . the limited nature of the holding in Brown," plying to a nondiscriminatory ad valorem property tax, ${ }^{71}$ and held that such a levy fell within the scope of the Clause's prohibition. ${ }^{72}$ Low, it followed, had been incorrectly decided and was therefore overruled.

Finally, there was the matter of disposing of the case the parties had litigated, which the Court accomplished in a brief paragraph. The Gwinnett County property tax was nondiscriminatory on its face and no contention was made that it was being discriminatorily applied. The only other inquiry indicated by the Court's analysis was whether the tires were still in transit. The record shed little light on this issue, ${ }^{73}$ and the state courts had made no findings regarding it. The Supreme Court, apparently unperturbed by the fact that the parties had directed most of their attention to questions of packaging and had been given no opportunity to develop, in light of the Court's

$$
\begin{array}{lll}
{ }^{67} 423 \text { U.S. at } 298 . & 69423 \text { U.S. at } 294 . & 71 \text { Id.at } 282 . \\
{ }^{68} 13 \text { Wall. } 29(1872) . & 70 \text { Id. at } 298 . &
\end{array}
$$

72 The Court added that the Court in Low had compounded its errors in misreading Brown by misreading Chief Justice Taney's views in The License Cases, 5 How. 504,573 (1847), as well. 423 U.S. at 299-301. Taney had indicated his agreement with Marshall that "goods imported, while they remain in the hands of the importer, in the form and shape in which they were brought into the country, can in no just sense be regarded as a part of that mass of property in the State usually taxed for the support of the State government." 5 How. at 575 . The Low opinion had seized upon this language in support of its conclusion. 13 Wall. at 33-34. Taney, however, had gone on to distinguish a tax on imports as such from a tax on all property owners, noting that "the importing merchant is liable to this assessment like any other citizen, and is chargeable according to the amount of his property, whether it consists of money engaged in trade, or of imported goods which he proposes to sell," 5 How. at 576. The Court in Low did not refer to this passage.

${ }^{73}$ There appears to be nothing in the record regarding the average length of time a tire remains in the Gwinnett County warehouse, a fact that would seem to have a critical bearing on the question whether the goods are in transit. 
new wisdom, a factual record and legal arguments on the issue, ${ }^{74}$ decided the question summarily: ${ }^{75}$

Petitioner's tires in this case were no longer in transit. They were stored in a distribution warehouse from which petitioner conducted a wholesale operation, taking orders from franchised dealers and filling them from a constantly replenished inventory. The warehouse was operated no differently than would be a distribution warehouse utilized by a wholesaler dealing solely in domestic goods.

The Court's terse treatment of what turned out to be the critical factual issue in the case contrasts strikingly with its leisurely and discursive exploration of the historical issues raised. Whether this makes Michelin an uncertain guide to the future is the question to which I now turn.

\section{State Taxation of Imports after Michelin}

\section{A. THE ANALYTICAL FRAMEWORK}

In the wake of Micbelin, courts confronting a taxpayer's claim under the Import-Export Clause that a state tax constitutes a prohibited "impost" or "duty" on "imports" will be operating in a new decision-making framework. Prior to Micbelin the central aim of the vast majority of judicial inquiries into such a contention was to locate the imported goods in time and space in the context of their intended use to determine whether they had retained their distinctive character as imports. ${ }^{\text {Th }}$ While the nature of the exaction at issue was sometimes examined in the course of such an inquiry, ${ }^{7 \pi}$ this was generally no more than a secondary consideration. Michelin suggests that these analytical priorities should be reordered.

A court's first task should henceforth be to determine whether the

${ }^{74}$ The parties had taken occasion to draw conflicting inferences from the record whether the "flow of import distribution" terminated at the Gwinnett County warehouse, compare Reply Brief for Petitioner, p. 9, with Brief for Respondent, p. 13, or whether the imported tires continued to "flow out from Michelin's warehouse to tire dealers scattered throughout six states." Reply Brief for Petitioner, p. 9.

75423 U.S. at 302.

"See, e.g., cases cited supra, at notes 27-35.

${ }^{77}$ See, e.g., May v. New Orleans, 178 U.S. 496 (1900). 
levy in question is in fact an "impost" or "duty" within the meaning of the Import-Export Clause. If it is not, no consequence attaches to whether the goods have lost their status as "imports." To be sure, one could argue that if goods have lost their status as "imports," no consequence attaches to whether they have been subjected to an "impost" or "duty." But it seems clear that the purposes of the Clause may be more faithfully served by pursuing the first line of analysis rather than-or at least prior to-the second. As the Court's opinion in Michelin demonstrates, one can rationally and systematically examine the legality of a challenged levy in light of the objectives of the Clause. By contrast, the Court's efforts over the past I 50 years to delineate the scope of the Clause's protection by reference to whether goods had retained their status as imports have met with limited success, ${ }^{78}$ and, indeed, have led to the very error that Micbelin has sought to correct. Although it might be postulated that the Court's past failures in this regard were due simply to the lack of attention it paid to the purposes of the Clause and not to any inherent weakness in the structure of its analysis, those purposes seem capable of being more sensibly related to the character of an exaction than to the character of imported goods. ${ }^{79}$

It should be emphasized that this initial inquiry is not to be narrowly limited to the textual question whether the exaction at issue is an "impost" or "duty" as Professor Crosskey-and now, it seems, the Court-have construed those terms. For even after strongly intimating that a nondiscriminatory ad valorem property tax did not fall within the wording of the Import-Export Clause's prohibi-

${ }^{78}$ See Dakin, note 32 supra; Early \& Weitzman, note 12 supra; Powell, note 11 supra; Trickett, note 35 supra.

${ }^{79} \mathrm{An}$ attempt to restructure the inquiry in Micbelin by focusing on the question whether the tires retained their status as imports suggests some of the problems involved. Instead of asking whether a nondiscriminatory ad valorem property tax would undermine the federal government's regulation of foreign relations, deprive it of expected revenues, or interfere with the free flow of imported goods among the states, one would ask whether a tax on tires stored in a Gwinnett County warehouse under the circumstances described above, see text supra, at notes 13-19, would do so. Without referring to the nature of the exaction involved it is difficult to devise an analytically satisfactory method of approaching the issue. One could, perhaps, inquire whether such goods in their particular form and commercial context were goods of the type over which the federal government was intended to have exclusive regulation, or from which it expected to derive revenue, or upon which a state tax might interfere with the free flow of imported goods among the states. Yet the form-and-commercial-context criterion provides a much less precise basis for analysis than the words of a state tax statute. 
tion, ${ }^{80}$ the Court makes it clear that whatever ambiguity there might be in those terms, ${ }^{81}$ a nondiscriminatory property tax imposed on goods no longer in transit is not forbidden by the Clause. The provision is not to be construed "to embrace taxation that does not create the evils the Clause was specifically intended to eliminate."

The controlling question, then, at this stage of the analysis is whether a challenged tax disserves the underlying purposes of the Import-Export Clause. In theory, this could require an undertaking to determine whether the imposition of the tax at issue would threaten the federal government's exclusive regulation of foreign commerce, divert anticipated federal import revenues to the states, or interfere with the free flow of imported goods among the states. ${ }^{83}$ As a practical matter, however, a court may accomplish the same thing by undertalking the more manageable task of determining whether the exaction discriminates against imported goods on the basis of their foreign origin. The answer to the latter question will provide the answer to the former, as the Supreme Court's own opinion reveals. For the Court appears in effect to have translated the former considerations into the single operational issue of discrimination. Thus, in determining whether a nondiscriminatory ad valorem property tax would offend the objectives noted above, the Court rooted its conclusion in the facts that "such a tax does not fall on imports as such because of their place of origin," 84 "cannot be selectively imposed and increased so as substantially to impair or prohibit importation," 85 and is not "directed solely at imported goods."so

If a court concludes that the levy at issue does not discriminate against imported goods on the basis of their foreign origin, the Supreme Court's opinion plainly indicates that there is still a further question to be considered, namely, whether the goods are still in transit through the state. The doctrinal basis for this inquiry is unclear. The Court suggests a number of times that the issue whether an exaction is an "impost" or "duty" within the meaning of the Clause can be determined simply by examining its terms and without regard to its application to particular facts, such as whether goods
${ }^{80}+23$ U.S. at $290-94$.
${ }^{84} I d$. at 286.
${ }^{81}$ Id. at 293.
85 Id. at 288.
82 Id. at 293-94.
${ }^{86} \mathrm{Ibid}$.
${ }^{83}$ Id. at 283-90. 
are in transit. Thus the Court states that "a nondiscriminatory ad valorem property tax is not the type of state exaction which the Framers of the Constitution or the Court in Brown had in mind as being an 'impost' or 'duty," "\$st and that "prohibition of nondiscriminatory ad valorem property taxation would not further the objectives of the Import-Export Clause." 88 Yet, the Court unmistakably confines its holding to petitioner's tires which were "no longer in transit." $\$$ Moreover, it specifically observes that insofar as there is any conflict between the preservation of the free flow of imported goods among the states and the imposition of a nondiscriminatory ad valorem property tax, the Clause's purpose "may be secured merely by prohibiting the assessment of even nondiscriminatory property taxes on goods which are merely in transit through the State when the tax is assessed." Whether the Court is saying that an exaction not otherwise an "impost" or "duty" becomes one when imposed upon goods in transit or, alternatively, that there is a "protected penumbra" 91 of guarantees beyond the explicit terms of the Clause that would bar such an exaction, ${ }^{92}$ a court must consider this issue in examining a taxpayer's clain that a state tax is a prohibited tax on imports, if it has concluded that the levy does not discriminate against such goods. ${ }^{93}$

On the other hand, if a court concludes that a levy is in fact an "impost" or "duty," there remains in principle the question whether the levy has been imposed upon an "import." This would presumably trigger the application of the "original package" doctrine and related criteria for determining whether particular goods have retained their distinctive character as imports. Notwithstanding the Court's restructured approach to the underlying issue, it did nothing to discredit the evidentiary tests for drawing the line between "im-

\footnotetext{
${ }^{87} \mathrm{Id}$. at 283.

${ }^{89} \mathrm{Id}$. at 302 .

${ }^{88} I d$. at 293. See also id. at 282, 286, 301.

${ }^{90} I d$. at 290.

${ }^{91}$ Griswold v. Connecticut, 381 U.S. 479, 487 (1965) (Goldberg, J., concurring).

${ }^{92}$ It is apparent that the Court finds this authority somewhere in the ImportExport Clause because it notes in the margin that such a levy "would also be invalid under traditional Commerce Clause analysis." 423 U.S. at 290 n.11. It may be worth recalling in this context that the Court explicitly declined to reach the question whether Michelin's tires had lost their status as imports, even while concluding that they were no longer in transit. See 423 U.S. at 279, 302.

${ }^{93}$ The criteria for making this determination are discussed infra, at notes $120-42$.
} 
ports" and "the mass of property in the country." ${ }^{4}$ Nevertheless, in light of the Court's analysis of the nature of an "impost" or "duty" -now confined essentially to those taxes discriminating against imports by virtue of their foreign origin ${ }^{95}$-the range of application of these tests will be much more limited. ${ }^{96}$ One could even contend that it would be a definitional impossibility to have an "impost" or "duty" that was not imposed upon an "import"-thus doing away altogether with the need for the various evidentiary tests. If the Court was in fact convinced by Crosskey's "persuasive demonstration that the words 'imposts' and 'duties' as used in 1787 had meanings well understood to be exactions upon imported goods as imports," the determination that a tax was an "impost" or "duty" would carry with it a rather strong implication that the goods in question were "imports." While the Court did not go this far, it is plain that the significance of those tests designed to aid in ascertaining when an import ceases to be an import has been greatly diminished. Moreover, the Court makes it clear that there is ample doctrinal authority to invalidate any tax effectively discriminating against imports regardless of mechanical distinctions based on the timing of the levy ${ }^{\text {as }}$ or the form of the goods. ${ }^{99}$

\section{B. DECISION-MAKING}

Micbelin teaches that nondiscriminatory ad valorem property taxes are not "imposts" or "duties" within the meaning of the Import-Export Clause, at least when the goods sought to be taxed are not in transit. At the same time, Micbelin raises two key questions that will require judicial resolution on a case-by-case basis. First, whether other types of state taxes constitute "imposts" or

"Brown, 12 Wheat. at 441 . Indeed, it reaffirmed them, but in the context of its revised analysis. 423 U.S. at $287,296-97$.

95 But see text supra, at notes 87-92.

${ }^{[n S}$ Indeed, most cases in recent years involving challenges to state taxes as forbidden levies on imports have arisen under nondiscriminatory ad valorem property taxes. See notes 100-01 infra. Assuming no discriminatory application, an importer will most likely be limited to the claim that the goods are still in transit insofar as this category of exactions is concerned.

97423 U.S. at 290-91; see also $i d$. at 297-98.

os Id. at 288 n.7.

00 Id. at 297. 
"duties" as Michelin has construed those terms. Second, whether particular goods are "in transit."

1. "Imposts" or "duties." As the preceding discussion suggests, Micbelin seems to provide both an analytical framework and substantive guidelines for determining whether particular state taxes are "imposts" or "duties." Although most cases in recent years involving state taxation of imports have arisen under nondiscriminatory ad valorem property taxes ${ }^{100}$ and are thus specifically controlled in this respect by Micbelin's holding, ${ }^{101}$ nonproperty taxes have been ${ }^{102}$ and will no doubt continue to be the focus of such controversies. It may therefore be instructive to examine one or two earlier decisions of the Supreme Court involving challenges to nonproperty taxes under the Import-Export Clause to observe the application of Michelin's new learning in this context. The two most recent Supreme Court cases involving successful challenges to nonproperty taxes on the grounds that the taxes violated the prohibition against laying "imposts" or "duties" on imports are Anglo-Chilean Nitrate Sales Corp. v. Alabamna and Department of Revemue v. James B. Beam Distilling Co. ${ }^{104}$

In the Anglo-Cbilean case, the taxpayer, a New York corporation qualified to do business in Alabama, was engaged in the importation of nitrate through Mobile and other ports. The nitrate was brought into Mobile in hundred-pound bags and stored in a public warehouse in the original packages until sold and delivered to customers. The parties agreed that the "landing, storage and sale of the

${ }^{100}$ Of the Courr's three latest opinions dealing with the question of state taxation of imports, two, Micbelin and Youngstown Sbeet \& Tube, have involved nondiscriminatory ad valorem property taxes. The other, Department of Revenue v. James B. Beam Distilling Co., 377 U.S. 341 (1964), is considered infra, at notes 113-19. Over the same time period, the vast majority of state court cases dealing with state taxation of imports have likewise involved nondiscriminatory ad valorem property taxes. See, e.g., CCH State Tax Cases [1958-75 Transfer Binders] (13 of 16 cases there reported dealing with state taxation of imports involve nondiscriminatory ad valorem property taxes).

${ }^{101}$ The reference to Michelin's holding is not intended to embrace the question whether particular goods are in transit.

${ }^{102}$ See, e.g., Volkswagen Pacific, Inc. v. City of Los Angeles, 7 Cal.3d 48 (1972) (franchise tax); Caterpillar Tractor Co. v. Department of Revenue, $47 \mathrm{Ill.2 \textrm {d }} 278$ (1971) (use tax); Miehle Printing Press and Mfg. Co. v. Department of Revenue, 18 Ill.2d 445 (1960) (sales tax); Citroen Cars Corp. v. City of New York, 30 N.Y.2d 300 (1972) (franchise tax).

${ }^{103} 288$ U.S. 218 (1933). ${ }^{104} 377$ U.S. 341 (1964). 
nitrate ... [were] the only transactions in Alabama in which appellant is concerned."105 Alabama's corporate franchise tax statute provided then, substantially as it does now, that "every corporation organized under the laws of this State ... shall pay annually to the State an annual franchise tax of Two Dollars (\$2.00) on each One Thousand Dollars of its capital stock"106 and that "every corporation organized under the laws of any other state, nation, or territory, and doing business in this State ... shall pay annually to the State an annual franchise tax of Two Dollars (\$2.00) on each One Thousand Dollars of the actual amount of capital employed in this State."107 Under the latter provision, Alabama assessed its franchise tax against Anglo-Chilean, measured by the value of its nitrate stored in Alabama.

The taxpayer challenged the exaction under both the ImportExport and Commerce Clauses, and the Supreme Court sustained the challenge on both grounds. ${ }^{108} W$ ith regard to the former contention, the Court stated: ${ }^{109}$

The right to import the nitrate included the right to sell it in the original bags while it remained the property of appellant and before it lost its distinctive character as an import. State prohibition of such sales would take from appellant the very rights in respect of importation that are conferred by the Constitution and laws of the United States. Alabama was powerless, without the consent of Congress, to tax the nitrate before such sales or to require appellant by the payment of occupation or franchise tax or otherwise to purchase from it the privilege of selling goods so imported and handled.

The question is whether such reasoning can survive Michelin. The answer is probably negative. The tax had none of the vices that the Court identified as characteristic of "imposts" and "duties." It did not fall on imports as such because of their foreign origin,

105288 U.S. at 225.

${ }^{1063}$ Section 53 of Act No. 163, Ala. General Acts, 1927, p. 176, now Ala. Code tit. $51, \$ 347$ (1958, Supp. 1973). The rate has been increased from $\$ 2.00$ to $\$ 3.00$.

107 Section 54 of Act No. 163, Ala. General Acts, 1927, p. 176, now Ala. Code tit. $51, \$ 348$ (1958, Supp. 1973).

${ }^{10 y}$ It is questionable whether the Court's Commerce Clause analysis in AngloChilean is consistent with modern precedents in this area. See Hellerstein, note 62 supra, at 176-92.

${ }^{100} 288$ U.S. at 225-26. 
but rather fell on all profit-making foreign corporations, regardless of their business, and was measured by their capital employed in the state regardless of its nature. It could not be selectively imposed and increased so as substantially to impair or prohibit importation since any increase would necessarily impinge equally on other foreign corporations doing business in the state, whatever the nature of their business. And it was not directed solely at imported goods as is evident from the face of the statute. Furthermore, it was clear that the Alabama taxing scheme did not discriminate against foreign corporations, although this fact in itself would not support an ImportExport Clause objection however objectionable it might be under the Commerce Clause. As Justice Frankfurter noted, the tax which the Court struck down in Anglo-Cbilean Corp. was a "non-discriminatory $\mathrm{ta}[\mathrm{x}]$ which fell equally on imported and domestic goods similarly situated."110 A nondiscriminatory franchise tax imposed upon all foreign corporations doing business in the state measured by the value of the capital there employed is therefore not "the type of state exaction which the Framers of the Constitution or the Court in Brown had in mind as being an 'impost' or 'duty.' "111 The possibility remains, however, that the tax would nonetheless be barred under the Import-Export Clause on the basis of an "in transit" or equivalent ${ }^{112}$ limitation.

In James Beam, a liquor distributor imported whiskey into the United States from Scotland and stored it in a Kentucky warehouse prior to sale on the domestic market. A Kenteacky statute provided: "No person shall ship or transport or cause to be shipped or transported into the state any distilled spirits from points without the state without first obtaining a permit from the department and paying a tax of ten cents on each proof gallon contained in the shipment." ${ }_{113}$ Pursuant to the statute, the Kentucky tax authorities required James Beam to pay a tax of 10 cents on each proof gallon of whiskey it had imported from Scotland. It was agreed that "the tax was collected while the whiskey remained in unbroken packages in the hands of the original importer and prior to resale or use by the importer."114

${ }^{110}$ Youngstown Sbeet \& Tube, 358 U.S. at 574 (Frankfurter, J., dissenting).

111423 U.S. at 283.

${ }^{112}$ See text infra, at notes 120-42 and especially text at notes $140-42$ and note 142 .

${ }^{113}$ Quoted 377 U.S. at 342.

114377 U.S. at 342. 
The taxpayer contended that the Kentucky levy constituted a proscribed "impost" or "duty" on "imports." The critical issue in the case was whether the Twenty-first Amendment ${ }^{115}$ had lowered the barriers of the Import-Export Clause with respect to state taxation of intoxicants. ${ }^{16}$ In the course of an opinion holding that it had not, the Court stated: ${ }^{117}$

The tax here in question is clearly of a kind prohibited by the Export-Import Clause. Brown v. Maryland. ... As this Court stated almost a century ago in Low v. Austin, . . . a case involving a California ad valorem tax on wine imported from France and stored in original cases in a San Francisco warehouse, "the goods imported do not lose their character as imports, ... until they have passed from the control of the importer or been broken up by him from their original cases. Whilst retaining their character as imports, a tax upon them, in any shape, is within the constitutional prohibition."

While it is apparent that this reasoning cannot survive Michelin, the result is not likely to be affected. In contrast to the tax at issue in the Anglo-Cbilean case, the Kentucky levy had many of the earmarks of an "impost" or "duty." It fell on imports as such, although the statutory classification was broad enough to include out-of-state as well as foreign goods. It could be selectively imposed and increased to impair or prohibit importation, although, again, the impairment or prohibition would extend to out-of-state as well as foreign goods. And it was discriminatory on its face, directed solely at goods imported from abroad or out-of-state. ${ }^{118}$ Under these circumstances, and in light of the undisputed facts relating to the status of the whiskey as an import, the conclusion that the Kentucky

115 "The transportation or importation into any State, Territory, or possession of the United States for delivery or use therein of intoxicating liquors, in violation of the laws thereof, is hereby prohibited." U.S. Consr. Amend XXI, $\$ 2$.

${ }^{113}$ The Court had "made clear in the early years following adoption of the Twenty-first Amendment that by virtue of its provisions a State is totally unconfined by traditional Commerce Clause limitations when it restricts the importation of intoxicants destined for use, distribution, or consumption within its borders." Hostetter v. Idlewild Bon Voyage Liquor Corp., 377 U.S. 324, 330 (1964).

117377 U.S. at 343.

${ }^{118}$ Despite the fact that the statute was facially discriminatory, the suggestion has been made that it might not have been so in application since Kentucky imposed an equivalent tax on the manufacture of liquor. Note, The Supreme Court, $1963 \mathrm{Term}$, 78 HARv. L. Rev. 143, 239 n.16 (1964). The Court, however, showed no awareness of this fact. lbid. 
levy as applied in James Beam violated the Import-Export Clause would probably command a majority of votes in the Supreme Court today. ${ }^{119}$

2. "In transit." Unlike the guidance the Court's opinion provides for making the determination whether a tax is an "impost" or a "duty," it provides virtually no assistance with regard to the determination whether goods are still "in transit." The Court made only three brief references to this issue. It noted that the historical purposes of the Import-Export Clause did not embrace a nondiscriminatory ad valorem property tax imposed on imported goods that were "no longer in import transit"; ${ }^{120}$ that insofar as the Clause was designed to prevent the exactions of transit fees on the privilege of moving through a state, this purpose could be secured by prohibiting the assessment of such taxes on goods that were "merely in transit through the State when the tax is assessed"; ${ }^{121}$ and that Michelin's tires were "no longer in transit," 122 having been stored in its warehouse to meet the demands of its wholesale operation.

It is conceivable, of course, that the Court provided no further guidance on this point because it felt none was necessary or useful. After all, the term is hardly new to the law, ${ }^{123}$ and the question whether goods are in transit almost inevitably leads to nice distinctions between cases based on their particular facts about which generalizations are of little value. Nevertheless, because the Michelin opinion did not employ the term with complete consistency, the Court's failure to elaborate its discussion raises several issues.

The most important is whether the Court intended to draw a distinction between the generally accepted meaning of the term "in transit"-in the course of transportation from a specific origin to a

119 One may not be able to determine whether a levy discriminates against foreign goods simply by examining the terms of a statute. Thus a tax upon a particular category of goods, which in fact are produced only abroad, though nondiscriminatory on its face may discriminate against such goods unless an equivalent tax is imposed on different but competing goods produced within the taxing state. See Note, National Power to Control State Discrimination against Foreign Goods and Persons: $A$ Study in Federalism, 12 Stan. L. Rev. 355, 360-62 (1960). Such discriminatory taxes would seem to be vulnerable to attack under either the Import-Export Clause or the Commerce Clause. See id. at 364; text, infra, at notes 166-70. An instructive discussion of a closely analogous problem arising under the General Agreement on Tariffs and Trade appears in DaM, The GATT: LAw and INTERNational Economic Organization 116-21 (1970).

120423 U.S. at 286.

121 ld. at 290.

122 Id. at 302.

${ }^{123}$ See, e.g., 80 A.L.R.2d 445 (1961). 
specific destination-and its meaning in the context of importation. One could argue, on the basis of the Court's reference to goods "in import transit," that the Court had in mind a broader concept of transport journey than is ordinarily associated with the shipment of goods from one point to another. Drawing on Chief Justice Taney's language in The License Cases, ${ }^{124}$ quoted with approval by the Court in Youngstown Sheet of Tube $e^{125}$ and cited with approval in Micbelin, ${ }^{120}$ one could further contend that such "import transit" must be deemed to continue until the goods reach the point where they are to be used, consumed, or sold: ${ }^{127}$

The immense amount of foreign products used and consumed in this country are imported, landed, and offered for sale in a few commercial cities, and a very small portion of them are intended or expected to be used in the State in which they are imported.... And while they are in the hands of the importer for sale, in the form and shape in which they were introduced, and in which they are intended to be sold, they may be regarded as merely in transitu, and on their way to the distant cities, villages, and country for which they are destined, and where they are expected to be used and consumed, and for the supply of which they were in truth imported. And a tax upon them while in this condition, for State purposes, whether by direct assessment, or indirectly, by requiring a license to sell, would be hardly more justifiable in principle than a transit duty upon the merchandise when passing through a State.

On the basis of such reasoning and authority, one could make a case for the proposition that, whatever meaning "in transit" may have in other contexts, "import transit" continues until goods have reached the destination of their intended use, consumption, or sale whether or not they were stored or otherwise deliberately delayed en route.

There are, however, several reasons why such an interpretation of the Court's opinion should be rejected. First, judging solely by the Court's language in Micbelin set forth above, there is no indication that it intended to draw the proposed distinction or to accord its single use of the term "import transit" any special significance. Second, Michelin's reading of the purpose of the Import-Export Clause-to prohibit discrimination against imports-carries with it

1245 How. at 575-76.

${ }^{125} 358$ U.S. at 540 n.6.
126423 U.S. at 290 n.10.

${ }^{127} 5$ How. at 575-76. 
no implication that it should be construed to justify discrimination in their favor; and to provide goods upon an import journey with protection not afforded similarly situated goods upon an interstate journey would permit the latter type of discrimination. Indeed, the Court's observation that such an assessment upon goods "in transit" would otherwise be invalid under traditional Commerce Clause analysis ${ }^{128}$ affirmatively suggests that it did not intend to bestow upon imported goods in "import transit" an immunity from taxation unavailable to domestic goods in "interstate transit." Third, the Court in Michelin specifically cautions against misreading Taney's opinion in The License Cases, ${ }^{129}$ and notes that Taney, consistently with the Court's own view, had made it "crystal clear that the prohibition applied only to state exactions upon imports as imports."13" Finally, the Court's rejection in Micbelin of the assertion that the tires were still in transit-in the flow of import distribution to their final destination at franchised tire dealers scattered throughout six states $^{131}$-is further evidence that the term is not to be given an expanded reading in this context.

Even assuming that the Court did not intend to attribute any special meaning to the term "in transit" for purposes of the determination whether imports are immune from state taxation, there is still the question where one ought to look for guidance in applying it in this framework. A logical place to begin is with cases involving imports. But there is a dearth of relevant precedent-"the controversies in this Court over the meaning of [the Import-Export Clause] have numbered less than a dozen in our entire history" ${ }^{132}$ and what precedent there is ${ }^{133}$ may be somewhat suspect after Micbelin. ${ }^{134}$ Probably a more fruitful source of assistance are cases arising under the Commerce Clause, not simply because there are more of them ${ }^{13 .}$

128423 U.S. at $290 \mathrm{n} .11$.

129423 U.S. at 299-301. Admittedly, the specific language of the Court referred to was different from that quoted in the text, but the warning against drawing unwarranted inferences from Taney's opinion in light of his full views on the matter was not a narrow one. See also note 72 supra.

130423 U.S. at 300. ${ }^{131}$ Brief for Petitioner, pp. 5-6, 10.

${ }^{132}$ Youngstown Sheet $\odot$ Tube Co., 358 U.S. at 553 (Frankfurter, J., dissenting).

${ }^{133}$ See, e.g., The License Cases, 5 How. at 575-76.

${ }^{134}$ See text supra, at note 129.

${ }^{135}$ With respect to controversies arising under the Commerce Clause, the Court has noted: "This Court alone has handed down some three hundred full-dress opinions spread through slightly more than that number of our reports." Northwestern States Portland Cement Co. v. Minnesota, 358 U.S. 450, 457-58 (1959). 
but more pertinently because the Court itself pointed to "traditional Commerce Clause analysis" as an alternative basis for finding that an assessment upon goods that are merely in transit would be constitutionally invalid. ${ }^{136}$

A leading case, Minnesota $v$. Blasius, ${ }^{137}$ involving a state property tax, sets forth the governing principles: ${ }^{138}$

[T The States may not tax property in transit in interstate commerce. But, by reason of a break in the transit, the property may come to a rest within a State and become subject to the power of the State to impose a nondiscriminatory property tax. ... The "crucial question," in determining whether the State's taxing power may thus be exerted, is that of "continuity of transit."...

If the interstate movement has not begun, the mere fact that such a movement is contemplated does not withdraw the property from the State's power to tax it. ... If the interstate movement has begun, it may be regarded as continuing, so as to maintain the immunity of the property from state taxation, despite temporary interruptions due to the necessities of the journey or for the purpose of safety and convenience in the course of the movement. ... The question is always one of substance, and in each case it is necessary to consider the particular occasion or purpose of the interruption during which the tax is sought to be levied. ...

Where property has come to rest within a State, being held there at the pleasure of the owner, for disposal or use, so that he may dispose of it either within the State, or for shipment elsewhere, as his interest dictates, it is deemed to be a part of the general mass of property within the State and is thus subject to its taxing power.

A considerable amount of judicial energy has been devoted to the implementation of these principles, and there is consequently a substantial and apposite body of case law ${ }^{\mathbf{1 3 9}}$ to guide courts and state $\operatorname{tax}$ administrators ${ }^{140}$ in determining whether imported goods are

1301423 U.S. at 290 n.11. $\quad{ }^{137} 290$ U.S. 1 (1933). $\quad{ }^{138}$ Id. at 9-10.

130 See, e.g., 71 AMr. Jur.2d $\$ \$ 245-47$ (1973); 171 A.L.R. 283 (1947).

${ }^{140}$ In fact, the Washington State Department of Revenue instructed its county assessors that the determination whether goods are moving in foreign commerce should now be made under the same "physical movement" test as is used to determine the taxability of goods moving in interstate commerce. Washington Department of Revenue Property Tax Bulletin No. 76-2 (25 March 1976), reported in Report Bulletin No. 38, $\llbracket 38.4$, P-H State and Local Taxes (All States Unit) (13 April 1976). 
still "in transit." While the question whether goods are "in transit" is generally regarded as a limitation on property taxation, ${ }^{141}$ it has its analogues in the context of nonproperty taxation where the issue may be whether there is a taxable "moment" or "event" in the state. ${ }^{142}$ In short, the standards developed under the Commerce Clause should provide appropriate criteria for resolving the "in transit" issue under the Import-Export Clause.

\section{THE IMPACT OF MICHELIN: WHO WANTS TO TAX MMPORTS?}

The day after the Micbelizi decision was handed down, the New York Times carried a front-page story with the headline: "High Court Removes Curb on Nonfederal Import Tax ... Justices Open Way for States, Cities and Counties to Increase Revenues."1+3 Soon thereafter, the leading tax services reported what to many of their subscribers must have been the same gloomy message: "U.S. High Court Expands States' Right to Tax Imports"; ${ }^{144}$ "U.S. Supreme Court Ruling Broadens Power of States to Tax Imports." ${ }^{145}$ Moreover, it was predicted that "many areas will revise their tax laws, to take fullest advantage of the implications of ... [the] ruling."148

That Michelin has broadened the states' power to tax imports is indisputable. By narrowly defining "imposts" and "duties," the Court has paved the way for the imposition of nondiscriminatory state levies upon imports that were previously impermissible. And this is more than an abstract point of constitutional theory. The proposition that nondiscriminatory ad valorem property taxes upon goods no longer in transit fall outside the pale of the Import-Export Clause had a direct impact outside Gwinnett County upon litigation

141 See, e.g., Blasizes, 290 U.S. 1; Hartman, State Taxation of Interstate ComMERCE 73-79 (1953); cf. the excerpe from Chief Justice Taney's opinion in The License Cases, quoted in the text supra, at note 127.

${ }^{142}$ See, e.g., Southern Pacific Co. v. Gallagher, 306 U.S. 167 (1939). Indeed, these decisions often rely on their property tax analogues. $1 d$. at 177; Independent Warehouses, Inc. v. Scheele, 331 U.S. 70, 80 (1947); Nashville, C. \& St. L. Ry. v. Wallace, 288 U.S. 249, 266 (1933). See Hartman, note 141 supra, at 138.

${ }^{143}$ N.Y. Times, 15 Jan. 1976, p. 1, cols. 1-2.

${ }^{144}$ Report Bulletin No. 27, \27.1, P-H State and Local Taxes (All States Unit) (20 Jan. 1976).

145 Report Letter No. 209, p. 1, CCH State Tax Cas. Rep. (All States) (10 Feb. 1976).

${ }^{146}$ N.Y. Times, 15 Jan. 1976, p. 20 , col. 7. 
involving not only Michelin itself ${ }^{147}$ but other importers as well. ${ }^{148}$ Furthermore, Micbelin induced changes at the administrative level. The Indiana State Tax Board announced that Micbelin would be interpreted to render imports subject to its property tax as of March 1976 and that the regulation pertaining to import exemptions would no longer be applicable. ${ }^{1+9}$ The Ohio Tax Commissioner issued a bulletin advising county auditors to commence levying its personal property tax against all imports under specified conditions. ${ }^{150}$

Yet, not every state legislature or state tax authority jumped on the bandwagon to exercise its newly revealed tax power. The Maryland legislature enacted a law allowing counties and Baltimore City to exempt from taxation imports in the hands of the importer in their original package. ${ }^{1: 1}$ The South Carolina authorities assured taxpayers that Michelin would precipitate no change in that state's rule determining when imports acquire a taxable situs in the state. ${ }^{152}$ And the Illinois Attorney General issued an opinion declaring that Michelin would have no effect on the state statute exempting from taxation certain personal property when stored in its original package in Illinois. ${ }^{153}$

More important than these isolated examples, however, is the plain fact that many states and their subdivisions have never sought to tax imports to the full extent that they were constitutionally permitted to do so. Thus over thirty-five states have enacted "free port" laws allowing goods to be stored in the state on a tax-free basis under specified conditions that would frequently exempt imports within

147 Michelin Tire Corp. v. County of San Mateo, 57 Cal. App.3d 332 (1976).

${ }^{14 \times}$ See, e.g., City of Farmers Branch v. Matsushita Electric Corp. of America, 537 S.W.2d 452 (Tex. 1976), cert. denied, 97 S. Ct. 164 (1976); City of Farmers Branch v. American Honda Motor Co., 537 S.W.2d 454 (Tex. 1976), cert. denied, 97 S. Ct. 161 (1976); Sears, Roebuck \& Co. v. County of Kings, 59 Cal. App.3d 446 (1976); Ralston Purina Co. v. County of Los Angeles, 56 Cal. App.3d 547 (1976); Japan Food Corp. v. County of Sacramento, 56 Cal. App.3d 442 (1976).

11:' Indiana State Tax Board Bulletin No. 76-27 (13 Feb. 1976), reported in Report Bulletin No. 44, it 44.10, P-H State and Local Taxes (All States Unit) (25 May 1976).

${ }^{160}$ Ohio Tax Commissioner's Bulletin No. 244 to All County Auditors, reported in 37 State Tax Rev. No. 11, p. 8 (16 March 1976).

${ }^{151}$ Maryland Laws 1976, Ch. 621 (S.B. 1042).

${ }^{152}$ Opinion of Attorney General No. 112 (April 1976), reported in Report Bulletin No. 1, $\llbracket 1.11$, P-H State and Local Taxes (All States Unit) (6 July 1976).

${ }^{153}$ Opinion of Attorney General No. NP-1125 (15 July 1976), reported in Report Bulletin No. 5, \$5.9, P-H State and Local Taxes (All States Unit) (3 August 1976). 
the state's constitutional taxing power. ${ }^{154}$ The purposes behind one such law were described as follows: ${ }^{155}$

Sponsors of the bill assert that its enactment will be beneficial to Oregon because Oregon is so geographically situated as to be a natural distribution point for commerce which either originates in or is destined to Washington, California and overseas points. ...

SB 424 is designed to enhance Oregon's status as a distribution center and to stimulate the state's economy. Its sponsors feel that its enactment will improve Oregon's competitive tax position and divert commerce through the state which otherwise would not accrue to Oregon.

It is hardly likely, given the underlying rationale for such provisions, that Michelin will trigger their wholesale repeal or revision. In addition, several states, most significantly New York and Pennsylvania, no longer even levy tangible personal property taxes, ${ }^{156}$ the principal source of contemporary controversy over the states' power to tax imports. ${ }^{157}$ The narrow holding of Michelin would therefore have no impact on existing taxing provisions in these states, and it is improbable that it would single-handedly provide the necessary impetus for the reintroduction of such taxes in these jurisdictions.

On balance, it is unlikely that many state legislatures will rush to take "fullest advantage" of the doctrinal changes wrought by Micbelin, but the decision is likely to affect the results in cases under litigation $^{158}$ and to create a climate in which the expectations of taxpayers and the determinations of tax administrators will redound to the benefit of the public fisc.

${ }^{154}$ CCH State Tax Guide (All States) $\$ 20-100$ (Chart of State Free Port Law Requirements) (1967). To qualify for free-port exemptions, goods generally must satisfy some or all of the following conditions: They must have an out-of-state origin and/or destination; they must be stored in a public or other facility not owned by the consignee or consignor; and they must remain in their original packages. Id. Such exemptions would embrace interstate "imports" as well.

${ }^{155}$ Ore. Sen. Tax Comm., Description of S.B. 424, quoted in Weycrhaeuser Co. v. State Tax Comm'n., 244 Ore. 561, 565-66 (1966). The act was adopted by the Oregon Legislature as Oregon Laws 1959, ch. 659, p. 1390 and now appears as O.R.S. 307.810-50 (1975).

${ }^{156}$ The others are Delaware and Hawaii.

${ }^{15 \tau}$ See note 100 supra. But not the only source. See note 102 supra.

${ }^{158}$ See cases cited supra, at note 148 . The Californin Legislature, however, has enacted a statute denying retroactive application of the Michelin decision to personal property tax assessments prior to the 1976-77 assessment year. California Laws 1976, Ch. 335 (A.B. 3061), reported in 37 State TAx Rev. No. 31, p. 2 (3 August 1976). 


\section{Final Thoughts on the Implications of Michelin}

"It would entail a substantial revision of the Import-Export Clause," the Court has said, "to substitute for the prohibition against 'any' tax a prohibition against 'any discriminatory' tax."159 In Micbelin, the Court in effect does just that by construing "Imposts or Duties on Imports" as levies discriminating against imports on the basis of their foreign origin. ${ }^{100}$ The caveat that even a nondiscriminatory property tax may not be imposed on goods still in transit and the possibility that the Court may modify its views when dealing with other types of exactions ${ }^{161}$ provide some basis for arguing that the Court's about-face may be less than 180 degrees. Nevertheless, the Court's reevaluation of the purposes underlying the Clause and its consequent restructuring of the constitutional analysis lay the groundwork for a more rational approach to future disputes over state taxation of imports than we have seen in the past. ${ }^{162}$

The Court's opinion also establishes a fairer basis for limiting the power of the states to tax imports. Although discrimination in favor of the importing process may be justifiable on the grounds that it was "part and parcel of the federal bargain,"163 it does not commend itself as a matter of equity. As the Court itself noted in reference to the costs of governmental services, "there is no reason why an importer should not bear his share of these costs along with his competitors handling only domestic goods."104 Although the Court's comment was directed to ad valorem property taxation-which it characterized as "the quid pro quo for benefits actually conferred by the taxing State,"105 the point has equal force in connection with other types of levies if one is concerned with equalizing the state and local tax burden on foreign and domestic goods. It is important, of course, that care be taken to assure that the imposition of even a nondiscriminatory levy does not threaten to saddle imports with a

${ }^{170}$ Richfield Oil Corp. v. State Board of Equalization, 329 U.S. 69, 76 (I946).

${ }^{106}$ "Beyond its frequent reiteration of the point that nondiscriminatory ad valorem property taxes fall outside of the purview of the Clause, the Court at times broadens its reference to "nondiscriminatory taxes" generally, 423 U.S. at 290, 298, and at one point states that the Clause "cannot be read to accord imported goods preferential treatment that permits escape from uniform taxes imposed without regard to foreign origin for services which the State supplies." Id. at 287.

${ }^{101}$ Cf. Powell, note 11 supra, at 867.

102 See text supra, at notes 78-79.

164423 U.S. at 287.

${ }^{1033}$ Powell, note 11 supra, at 867.

${ }^{165} \mathrm{Id}$. at 289. 
cumulative tax burden not borne by equivalent domestic products. Micbelin's "in transit" limitation seems fashioned to serve just this purpose. And as we have seen, there is nothing to prevent the states from according imports favorable tax treatment if they choose to do so as a matter of their own fiscal policy, Still, as a principle of constitutional adjudication under the Import-Export Clause, the nondiscrimination criterion represents a salutary solution both to the problems it was designed to resolve and to the problems its interpretation has created-discrimination against domestic goods.

If Micbelin replaces the physical/temporal criteria with the nondiscrimination principle as the central focus of the inquiry into the power of the states to tax imports, it raises two further questions that I will address here only briefly.

The first is whether there remains any significant difference between the standards governing the validity of a state tax upon imports under the Import-Export Clause and those governing its validity under the Commerce Clause. With the obvious exception of cases affected by the Twenty-first Amendment, ${ }^{166}$ it would appear that there does not. Under either rubric, discriminatory levies against imports would be struck down and nondiscriminatory levies sustained unless imposed on goods in transit. And there is no reason to believe that the criteria for determining whether a levy discriminates against imports or is imposed upon goods in transit would be any different under one clause than under the other. ${ }^{167}$ To be sure, there is language in earlier cases that the "absolute want of power to tax imports . . . until they [have] completely lost their character as such"168 was to be distinguished from the more limited Commerce Clause restraint which "dealt with no positive and absolute inhibition against the exercise of the taxing power, but determined whether a particular exertion of that power by a State so operated upon inter-

\footnotetext{
${ }^{166}$ See text supra, at notes $115-16$ and note 116.
}

${ }^{167}$ See Cook v. Pennsylvània, 97 U.S. 566, 574 (1878) (tax discriminating against foreign goods sold at auction invalid under Import-Export and Commerce Clauses), cited with approval at 423 U.S. 288 n.7; $i d$. at 290 n.11. Even assuming an identity between Import-Export Clause and Commerce Clause criteria with respect to the validity of a state tax on imported goods, there may be some basis for arguing that the test of reasonableness of state legislation in the foreign commerce area is generally more stringent than in the interstate commerce field. See Note, note 119 supra, at 358.

${ }^{168}$ American Steel \& Wire Co. v. Speed, 192 U.S. 500, 521 (1904). 
state commerce as to amount to a regulation thereof." 169 Nevertheless, if the absolute prohibition of the Import-Export Clause's ban against taxing imports is limited to discriminatory levies or to levies upon goods in transit-as Micbelin indicates-and if the limited prohibition of the Commerce Clause is absolute with respect to such levies-as traditional Commerce Clause analysis indicates ${ }^{170}$-then the suggested distinction no longer has substance in this context.

The second question concerns the implications of Micbelin with regard to analysis of controversies over the power of states to tax exports. Just two Terms ago, the Court in Kosydar v. National Casb Register Co. ${ }^{171}$ emphatically reaffirmed the "settled doctrine" 172 that the "essential question" in such cases is the "narrow one: is the property upon which a tax has been sought to be imposed an "export" ";it3 that the "essential problem" is therefore "to decide whether a sufficient commencement of the process of exportation has occurred so as to immunize the article at issue from state taxation"; ${ }^{174}$ and that this depends on the factual inquiry whether the article has begun "its physical entry into the stream of exportation." not the slightest hint that Ohio's nondiscriminatory ad valorem property tax there at issue might not be an "impost" or "duty" within the meaning of the Import-Export Clause. Indeed, three decades earlier the Court had explicitly rejected the argument that "the history of the Import-Export Clause shows that it was designed to prevent discriminatory taxes and not to preclude the levy of general taxes applicable alike to all goods." ${ }^{770}$ And it declined to "read the prohibition against 'any' tax on exports as containing an implied qualification." 177

Since Micbelin fails even to acknowledge the existence of this line of authority, it is hazardous to speculate on where the opinion leaves it. While we should recognize that the problems of judicial inter-

${ }^{169}$ Ibid. See also Sonneborn Bros. v. Cureton, 262 U.S. 506, 509-13 (1923); Hooven \& Allison, 324 U.S. at 655-66; Richfield Oil, 329 U.S. at 75-78.

${ }^{170}$ Halliburton Oil Well Cementing Co. v. Reily, 373 U.S. 64 (1963); Minnesota v. Blasius, 290 U.S. 1 (1933); HarTMaN, note 141 stipra, at 67-70, 73-78, 144.

171417 U.S. 62 (1974).

${ }^{173}$ Id. at 66.

172 Id. at 71 . ${ }^{174} I d$. at 67.

${ }^{175}$ Id. at 71. See generally Abramson, State Taxation of Exports: The Stream of Constitutionality, 54 N.C. L. Rev. 59 (1975)

${ }^{170}$ Richfield Oil, 329 U.S. at 76. ${ }^{177}$ Id. at 78 . 
pretation associated with taxation of imports are not symmetrical with those associated with taxation of exports, ${ }^{178}$ it would appear that the two approaches are analytically incompatible. Nevertheless, there are a number of reasons for believing that Micbelin will not seriously disturb the framework for determining whether a levy is a prohibited state tax on exports. First, there may be some basis for arguing that the prohibition against state taxes upon exports was part of a "larger design"179 that included the limitation upon Congress that "No Tax or Duty shall be laid on Articles exported from any State." 180 Considered as a whole, this "design" may be viewed as having effected a more extensive limitation upon the states' power to tax exports than was accomplished with respect to imports. ${ }^{1 \times 1}$ Second, in contrast to the decisions involving state taxation of imports which were described by Justice Frankfurter as "a confusing series of conflicting cases amidst which the States must blindly move in determining the extent of their constitutional power to tax," 182 the Court's decisions involving state taxation of exports have been commendably intelligible and consistent. ${ }^{183}$ The Court may be unwilling to abandon a rule whose simple "virtues" it has so recently admired. ${ }^{184}$ Finally, whether or not the doctrinal disparity between Micbelin and the export cases is reconciled, the ultimate inquiry in the vast majority of cases will not be substantially different. Assuming that the tax in question is nondiscriminatory, as most taxes are, decision will turn on whether the goods are in "import transit" 18.5 or in "the export stream"186 which amounts to essentially-though not

${ }^{178}$ As a practical matter, it would seem to be considerably easier to identify goods that have come from abroad than those that are heading there. The former will frequently have characteristics that readily distinguish them from the mass of domestic goods wbile the latter will not. The different problems in identification may provide a plausible explanation-though not necessarily a theoretical justification-for the use of different approaches to the issue of state taxation of imports and exports.

179329 U.S. at 77.

180 U.S. Consr. Art. $1, \$ 9$, cl. 5 .

181329 U.S. at 76-78.

${ }^{182}$ Youngstown Sheet \& Tube, 358 U.S. at 553. (Frankfurter, J., dissenting.)

${ }^{183}$ Abramson, note 175 supra, at 81.

${ }^{184}$ Kosydar v. National Cash Register Co., 417 U.S. 62, 71 (1974).

185423 U.S. at 286.

${ }^{186} \mathrm{Kosyd} d r, 417$ U.S. at 71. 
precisely ${ }^{187}$-the same question asked at different ends of the journey. ${ }^{188}$

\section{Conclusion}

A century ago, the Supreme Court held in Low v. Austin that a nondiscriminatory ad valorem property tax levied upon French champagne stored in its original package violated the prohibition against laying "any Imposts or Duties on Imports." Last Term in Micbelin, the Court decided that the imposition of such a tax upon French tires was valid whether or not they were stored in their original packages, since the Framers of the Import-Export Clause never intended to include exactions of this type within its scope. Perhaps we "arrive where we started And know the place for the first time." 189

${ }^{1 \mathrm{kT}}$ See note 178 supra.

${ }^{1 \mathrm{RS}}$ See note 139 supra.

1ng Eliot, Little Gidding, in The Complete Poems and Plays 145 (1952). 
HeinOnline -- 1976 Sup. Ct. Rev. 1341976 